\title{
Effects of concentration on in vivo absorption of a peptide containing protein hydrolysate
}

\author{
J E HEGARTY, P D FAIRCLOUGH, K J MORIARTY, M J KELLY, AND M L CLARK \\ From the Department of Gastroenterology, St. Bartholomew's Hospital, London
}

SUMMARY Amino acid absorption from a peptide-containing protein hydrolysate and an equivalent amino acid mixture over a range of concentrations of the two-such as is thought to be found in the normal intestine after a meal ${ }^{1}$ - has been studied using a jejunal perfusion technique in man. The relative rates of amino acid absorption from the protein hydrolysate and amino acid mixture varied markedly with concentration, demonstrating that the global hypothesis that peptides confer an advantage in amino acid absorption in vivo is too simple. There is a highly significant correlation between amino acid absorption and the concentrations of amino acid in the perfusate, whether this contained amino acid or protein hydrolysate, suggesting that, under these experimental conditions at least, the presence of distinct amino acid and peptide transport systems is relatively unimportant. Doubt is thus cast upon suggestions derived from previous intestinal perfusion experiments that intact peptide transport may be nutritionally significant in man.

The existence and independence of intestinal transport systems for amino acids and small peptides in animals and man has now been demonstrated. ${ }^{2}$ Intestinal perfusion studies in man demonstrating greater and more rapid amino acid absorption from four different protein hydrolysates containing small peptides than from equivalent free amino acid mixtures have been interpreted as suggesting that the peptide transport systems might be of nutritional importance. $^{345}$ However, each hydrolysate was studied only at a single concentration. As the relative rates of absorption of amino acids from single peptides and equivalent free amino acids are known to be critically dependent on concentration, ${ }^{678}$ the present study was designed to examine in vivo in man the effect of concentration on the relative rates of amino acid absorption from a protein hydrolysate containing a complex mixture of peptides of varying size and an equivalent free amino acid mixture.

\section{Methods}

LACTALBUMIN HYDROLYSATE AND EQUIVALENT FREE AMINO ACID MIXTURE

The hydrolysate of lactalbumin was prepared by Nestlé Technical Assistance (Lausanne, Switzerland)

Received for publication 17 August 1981 as follows. Crude lactalbumin obtained from whey during the commercial processing of milk was hydrolysed with pancreatin. The resulting digest was separated into peptide fractions by ultrafiltration and the approximate size of the peptides obtained was estimated by gel filtration on columns of Sephadex G10. As estimated by this technique, the preparation contained $20 \%$ free amino acids, $30-35 \%$ di-, tri-, and tetrapeptides, $20-30 \%$ larger oligopeptides up to MW 1500D and 10-20\% peptides above MW 1500D. It should be borne in mind that, because of the variation in the molecular weight of individual amino acids, this distribution is an approximation. An amino acid mixture simulating the amino acid composition of the hydrolysate was also prepared. Individual amino acid concentrations in solutions of protein hydrolysate (both free and peptide bound) and amino acid are compared in Table 1 . The amino acid composition of the preparations was derived from ion exchange chromatography of solutions of the hydrolysate and amino acid mixture as described below.

\section{PERFUSION TECHNIQUE}

Jejunal absorption of amino acids from protein hydrolysate and amino acids was studied in 18 normal healthy adult volunteers using the intestinal perfusion technique previously described. ${ }^{8}$ The study was approved by the Ethical Committee of St. Bartholomew's Hospital and informed consent was obtained from all subjects. Solutions containing pro- 
Table 1 Individual amino acid concentration (mmol/l) of a solution of lactalbumin hydrolysate and its equivalent free amino acid mixture containing $100 \mathrm{mmol}(1 \cdot 32 \mathrm{~g})$ total amino acids/l

\begin{tabular}{lcc}
\hline $\begin{array}{l}\text { Amino } \\
\text { acid }\end{array}$ & $\begin{array}{l}\text { Lactalbumin } \\
\text { hydrolysate }\end{array}$ & $\begin{array}{l}\text { Amino acid } \\
\text { mixture }\end{array}$ \\
\hline Asparagine & 11.3 & 11.9 \\
Threonine & $8 \cdot 8$ & 8.4 \\
Serine & $7 \cdot 1$ & 7.2 \\
Glutamine & 16.5 & 16.1 \\
Proline & 7.9 & 7.2 \\
Glycine & 3.4 & 3.7 \\
Alanine & 7.5 & 7.4 \\
Valine & 7.5 & 7.3 \\
Methionine & 1.8 & 1.8 \\
Isoleucine & 6.9 & 6.3 \\
Leucine & 9.6 & 9.4 \\
Tyrosine & 1.9 & 1.9 \\
Phenylalanine & 2.5 & 2.9 \\
Lysine & 7.1 & 6.5 \\
Histidine & 1.5 & 1.5 \\
Arginine & 1.9 & 1.9 \\
\hline
\end{tabular}

Individual amino acid concentration:

$$
\mathrm{mg} / 100 \mathrm{ml}=\frac{\text { Conc }(\mathrm{mmol} / \mathrm{l}) \times \mathrm{mol} \text { wt amino acid }}{10}
$$

tein hydrolysate and amino acids were infused at 20 $\mathrm{ml} / \mathrm{min}$. After an equilibration time of 30 minutes, three 10 minute samples were collected from the distal collecting orifice by simple siphonage into a vessel at $4^{\circ} \mathrm{C}$. Samples were stored at $-20^{\circ} \mathrm{C}$ until required for analysis.

Three concentrations of protein hydrolysate and amino acid mixture containing 40,70 , and $100 \mathrm{mmol} / \mathrm{l}$ total amino acid were used. At each concentration the two solutions were perfused in random order in six subjects. The test solutions contained polyethylene glycol (PEG) $2.5 \mathrm{~g} / 1$ labelled with $1 \mu \mathrm{Ci}{ }^{14} \mathrm{C}$ PEG/l (Radiochemical Centre, Amersham, Buckinghamshire). The tonicity of solutions was adjusted to $290-300 \mathrm{MOsm} / \mathrm{kg}$ by addition of $\mathrm{NaCl}$ and the $\mathrm{pH}$ to 7 by addition of $1 \mathrm{M} \mathrm{NaOH}$. The sodium content of perfusion solutions was measured by flame photometry.

\section{ANALYTICAL METHODS AND CALCULATION OF RESULTS}

Aliquots of the perfusion solutions containing amino acid or protein hydrolysate and their respective intestinal aspirates were hydrolysed under reflux conditions at $110^{\circ} \mathrm{C}$ for 24 hours with $6 \mathrm{M} \mathrm{HCl}$ in the presence of norleucine as internal standard to compensate for hydrolysis losses. After cooling, the amino acid content of the hydrolysed sample was estimated by ion exchange chromatography using a Locarte automatic loading amino acid analyser (Locarte Company, London, UK). The ${ }^{14} \mathrm{C}$ PEG content of the test solutions and intestinal aspirates was measured by liquid scintillation counting. ${ }^{9}$ Amino acid absorption was calculated using previously described formulae. ${ }^{10}$ Luminal disappearance of amino acid residues was taken to be equivalent to absorption. The significance of differences was assessed by the paired $t$ test. ${ }^{11}$

\section{Results}

Whereas five amino acids (isoleucine, leucine, methionine, proline, and arginine) were absorbed to a greater extent $(\mathrm{P}<0.05)$ from amino acid than from protein hydrolysate at the low concentration (40 $\mathrm{mmol} / \mathrm{l}(0.53 \mathrm{~g} / 100 \mathrm{ml})$ total amino acid $)$, these amino acids were absorbed equally well from protein hydrolysate and amino acid at the high concentration $(100 \mathrm{mmol} / \mathrm{l}(1.32 \mathrm{~g} / 100 \mathrm{ml})$ total amino acid) (Table 2, Fig. 1).

Table 2 Amino acid absorption (\% of perfused load) during jejunal perfusion of equimolar concentrations $\left(40,70,100 \mathrm{mmol} \propto \mathrm{NH}_{2} \mathrm{~N} / l\right)$ of lactalbumin hydrolysate and equivalent amino acid mixture

\begin{tabular}{|c|c|c|c|c|c|c|c|c|c|}
\hline \multirow{2}{*}{$\begin{array}{l}\text { Amino } \\
\text { acid }\end{array}$} & \multicolumn{3}{|c|}{$40 \mathrm{mmol} \propto \mathrm{NH}_{2} \mathrm{~N} / \mathrm{l}(0.53 \mathrm{~g} / 100 \mathrm{ml})$} & \multicolumn{3}{|c|}{$70 \mathrm{mmol} \times \mathrm{NH}_{2} \mathrm{~N} / \mathrm{l}(0.92 \mathrm{~g} / 100 \mathrm{ml})$} & \multicolumn{3}{|c|}{$100 \mathrm{mmol} \times \mathrm{NH}_{2} \mathrm{~N} / \mathrm{l}(1.32 \mathrm{~g} / 100 \mathrm{ml})$} \\
\hline & $\begin{array}{l}\text { Amino acid } \\
\text { mixture }\end{array}$ & $\mathbf{P}$ & $\begin{array}{l}\text { Lactalbumin } \\
\text { hydrolysate }\end{array}$ & $\begin{array}{l}\text { Amino acid } \\
\text { mixture }\end{array}$ & $\mathbf{P}$ & $\begin{array}{l}\text { Lactalbumin } \\
\text { hydrolysate }\end{array}$ & $\begin{array}{l}\text { Amino acid } \\
\text { mixture }\end{array}$ & $\mathbf{P}$ & $\begin{array}{l}\text { Lactalbumin } \\
\text { hydrolysate }\end{array}$ \\
\hline ILEU & $90 \cdot 0 \pm 4 \cdot 2$ & $<\cdot 05$ & $75 \cdot 6 \pm 3 \cdot 1$ & $76 \cdot 8 \pm 4 \cdot 1$ & $<\cdot 05$ & $50 \cdot 4 \pm 2 \cdot 6$ & $66.2 \pm 6.3$ & NS & $68 \cdot 3 \pm 6 \cdot 1$ \\
\hline LEU & $89.2 \pm 6.1$ & $<.05$ & $76 \cdot 9 \pm 3 \cdot 2$ & $79 \cdot 6 \pm 3.2$ & NS & $66 \cdot 0 \pm 2 \cdot 8$ & $66 \cdot 1 \pm 6 \cdot 3$ & NS & $62.4 \pm 7 \cdot 1$ \\
\hline MET & $85 \cdot 2 \pm 2.9$ & $<\cdot 05$ & $70 \cdot 3 \pm 6 \cdot 8$ & $77 \cdot 2 \pm 3 \cdot 1$ & $<.05$ & $69 \cdot 6 \pm 3 \cdot 1$ & $73 \cdot 1 \pm 4 \cdot 2$ & NS & $65 \cdot 1 \pm 10 \cdot 4$ \\
\hline ARG & $71 \cdot 1 \pm 5 \cdot 1$ & $<\cdot 05$ & $45 \cdot 1 \pm 6 \cdot 4$ & $67 \cdot 1 \pm 4 \cdot 3$ & NS & $67 \cdot 2 \pm 3 \cdot 8$ & $58 \cdot 1 \pm 8 \cdot 4$ & NS & $47.6 \pm 7.9$ \\
\hline PRO & $68 \cdot 2 \pm 6 \cdot 2$ & $<.05$ & $52 \cdot 3 \pm 3 \cdot 8$ & $63 \cdot 4 \pm 3 \cdot 0$ & $<\cdot 05$ & $38 \cdot 8 \pm 2 \cdot 7$ & $59.9 \pm 8.0$ & NS & $43 \cdot 2 \pm 10 \cdot 6$ \\
\hline VAL & $70 \cdot 5 \pm 10 \cdot 8$ & NS & $55 \cdot 1 \pm 4 \cdot 0$ & $70 \cdot 0 \pm 3 \cdot 4$ & $<.05$ & $53 \cdot 6 \pm 2 \cdot 9$ & $50.2 \pm 9.6$ & NS & $58.6 \pm 6.7$ \\
\hline ALA & $71 \cdot 0 \pm 5 \cdot 9$ & NS & $60 \cdot 1 \pm 6 \cdot 0$ & $60 \cdot 3 \pm 3 \cdot 3$ & NS & $53.3 \pm 2.9$ & $44 \cdot 3 \pm 10 \cdot 4$ & NS & $54 \cdot 3 \pm 9 \cdot 3$ \\
\hline LYS & $61 \cdot 2 \pm 8 \cdot 2$ & NS & $56 \cdot 2 \pm 3 \cdot 6$ & $47 \cdot 5 \pm 2 \cdot 7$ & NS & $46 \cdot 8 \pm 1 \cdot 8$ & $39.7 \pm 5.9$ & NS & $43.9 \pm 8.6$ \\
\hline GLY & $48.5 \pm 6.8$ & NS & $49 \cdot 7 \pm 6 \cdot 1$ & $39 \cdot 0 \pm 3 \cdot 7$ & NS & $34 \cdot 7 \pm 3 \cdot 1$ & $30 \cdot 6 \pm 6 \cdot 2$ & NS & $37 \cdot 2 \pm 7 \cdot 3$ \\
\hline TYR & $64 \cdot 1 \pm 10 \cdot 1$ & NS & $68 \cdot 0 \pm 5 \cdot 6$ & $60 \cdot 7 \pm 3 \cdot 2$ & NS & $57 \cdot 2 \pm 6 \cdot 8$ & $39.8 \pm 4.8$ & $<\cdot 05$ & $55 \cdot 1 \pm 9.5$ \\
\hline SER & $62.8 \pm 5.6$ & NS & $59 \cdot 3 \pm 3 \cdot 3$ & $45 \cdot 1 \pm 4 \cdot 1$ & NS & $35 \cdot 4 \pm 5 \cdot 3$ & $28 \cdot 8 \pm 8 \cdot 2$ & $<\cdot 05$ & $43.8 \pm 7.9$ \\
\hline PHE & $60 \cdot 1 \pm 7.6$ & NS & $66 \cdot 0 \pm 4 \cdot 8$ & $62 \cdot 6 \pm 3 \cdot 8$ & NS & $62 \cdot 7 \pm 3 \cdot 2$ & $44.6 \pm 5 \cdot 8$ & $<\cdot 05$ & $65 \cdot 1 \pm 5.9$ \\
\hline THR & $57.9 \pm 7.3$ & NS & $53 \cdot 6 \pm 2 \cdot 9$ & $39 \cdot 8 \pm 2 \cdot 9$ & NS & $37 \cdot 1 \pm 2 \cdot 6$ & $23 \cdot 3 \pm 4 \cdot 8$ & $<\cdot 05$ & $40 \cdot 1 \pm 7.8$ \\
\hline HIS & $56.4 \pm 7.6$ & NS & $61 \cdot 8 \pm 5 \cdot 2$ & $40 \cdot 1 \pm 3 \cdot 8$ & NS & $34 \cdot 9 \pm 2 \cdot 7$ & $24 \cdot 6 \pm 6 \cdot 8$ & $<.05$ & $51 \cdot 5 \pm 10 \cdot 8$ \\
\hline
\end{tabular}

Results are mean of six studies \pm SEM. 


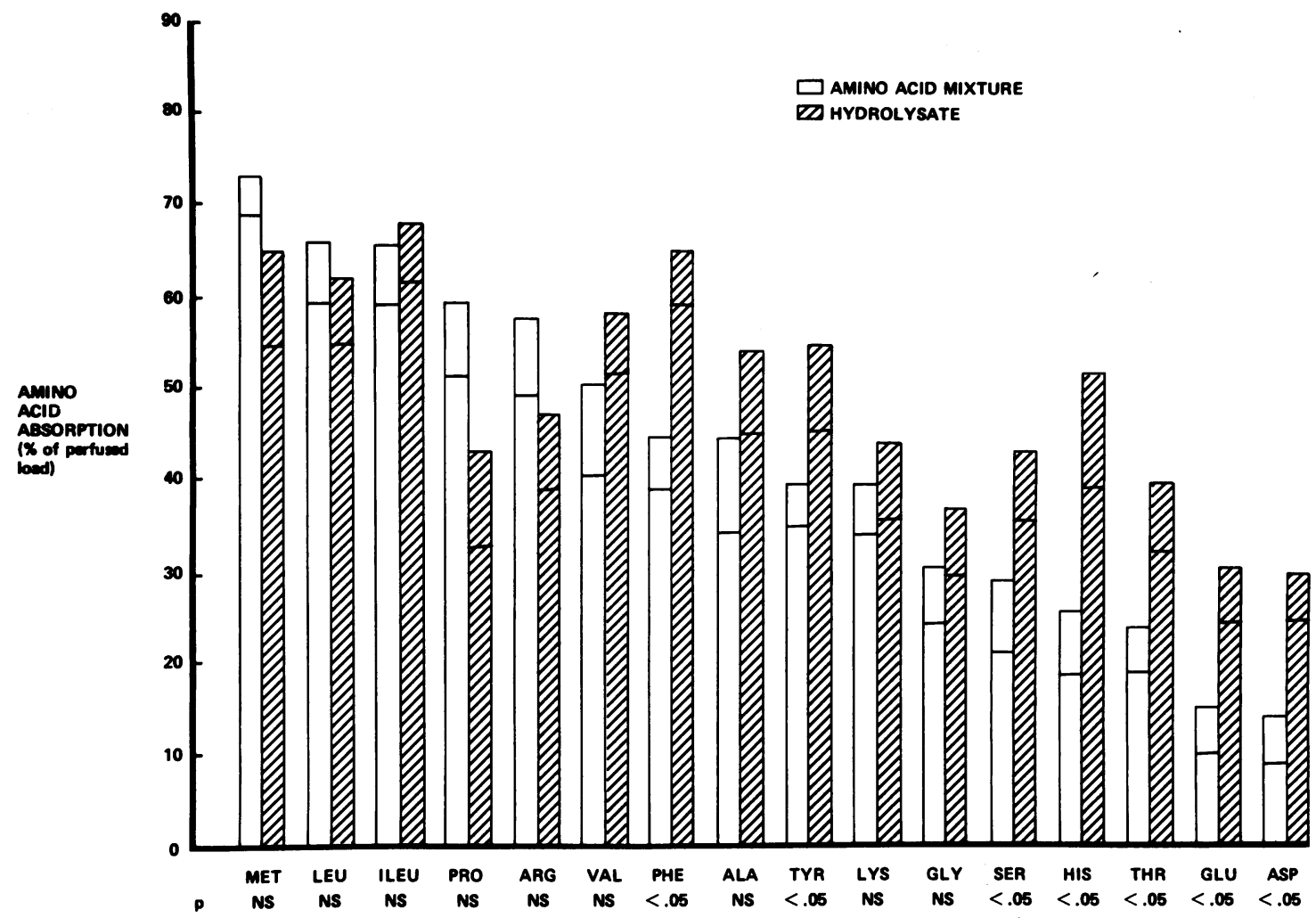

Fig. 1 Percentage absorption of individual amino acids from protein hydrolysate and amino acid mixture when both were perfused at $100 \mathrm{mmol} / \mathrm{l}(1 \cdot 32 \mathrm{~g} / 100 \mathrm{ml})$ total amino acid.

In contrast, a number of those amino acids (phenylalanine, tyrosine, serine, histidine, thronine, glutamine) which were absorbed to a similar extent from protein hydrolysate and amino acid mixture at the low concentration $(40 \mathrm{mmol} / \mathrm{l}(0.53 \mathrm{~g} / 100 \mathrm{ml})$ total amino acid) were absorbed to a greater extent $(\mathrm{P}<0.05)$ from hydrolysate at the high concentration $(100 \mathrm{mmol} / \mathrm{l}(1.32 \mathrm{~g} / 100 \mathrm{ml})$ total amino acid) (Table 2). During perfusion of the lactalbumin preparations containing total amino acid concentrations of 70 $\mathrm{mmol} / \mathrm{l}(0.92 \mathrm{~g} / 100 \mathrm{ml})$, four amino acids (leucine, methionine, proline, and valine) were absorbed to a greater extent from the amino acid mixture, while one amino acid (glutamine) was absorbed to a greater extent from protein hydrolysate. Asparagine was the only amino acid consistently absorbed to a greater extent from protein hydrolysate irrespective of concentration.

Figure 2 shows the actual amounts (in contrast with Fig. 1 which shows the percentage absorption) of each amino acid absorbed fom the protein hydrolysate and amino acid mixture when each was perfused at $100 \mathrm{mmol} / \mathrm{l}(1.32 \mathrm{~g} / 100 \mathrm{ml})$ total amino acid, suggesting that amino acid absorption is related more to the concentration of substrate than to the presence of specialised transport systems.

The sodium concentrations in the perfusion solutions are shown in Table 3 to demonstrate that the variation in their sodium content is small $(111.2$ to $146 \mathrm{mmol} / \mathrm{l})$.

Table 3 Sodium concentration (mmolll) of perfusion solutions containing lactalbumin hydrolysate and equivalent free amino acid mixture

\begin{tabular}{lcl}
\hline Preparation & $\begin{array}{l}\text { Concentration } \\
\text { (mmol/s total } \\
\text { amino acid/l }\end{array}$ & $\begin{array}{l}\mathrm{Na}^{+} \\
\text {concentration }\end{array}$ \\
\hline Lactalbumin & 40 & $146 \pm 3 \cdot 1$ \\
$\quad$ hydrolysate & 70 & $137 \cdot 3 \pm 2 \cdot 1$ \\
Free amino acid & 100 & $129 \cdot 7 \pm 3 \cdot 2$ \\
mixture & 40 & $136 \cdot 4 \pm 2 \cdot 1$ \\
& 70 & $123 \cdot 2 \pm 2 \cdot 3$ \\
& 100 & $111 \cdot 2 \pm 1 \cdot 9$ \\
\hline
\end{tabular}

Values are mean of six solutions $\pm 1 \mathrm{SD}$.

$* 40,70$, and $100 \mathrm{mmol} / \mathrm{l}=0.53,0.92$, and $1.32 \mathrm{~g} / 100 \mathrm{ml}$ respectively. 


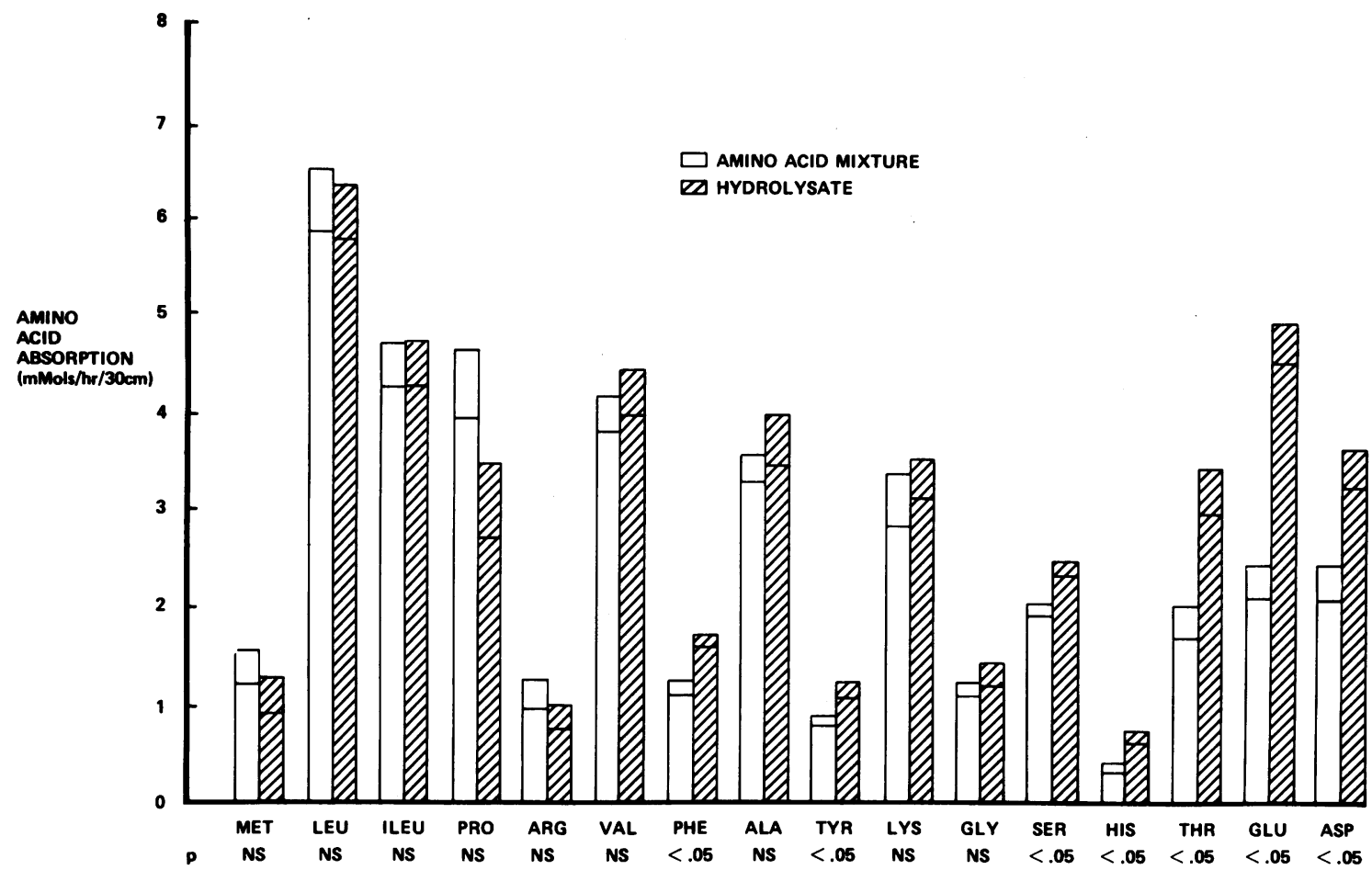

Fig. 2 Absolute amounts of individual amino acids absorbed from protein hydrolysate and amino acid mixture when both were perfused at $100 \mathrm{mmol} / \mathrm{l}(1.32 \mathrm{~g} / 100 \mathrm{ml})$ total amino acid.

\section{Discussion}

We have clearly shown that differences in the amino acid absorption between a protein hydrolysate and an equivalent amino acid mixture in the human jejunum are critically dependent on the concentration studied. At high concentration the phenomena previously observed with other hydrolysates ${ }^{3}{ }^{4} \mathrm{~b}$ have been confirmed in that there was significantly more rapid absorption from hydrolysates of those amino acids which were absorbed to the least extent from amino acid mixtures (Table 3, Fig. 1). At the lower concentration $(40 \mathrm{mmol} / \mathrm{l}(0.53 \mathrm{~g} / 100 \mathrm{ml})$ total amino acid), however, the pattern of 'kinetic' advantage' completely altered. At this concentration those amino acids which were absorbed to the greatest extent from amino acid mixtures were absorbed significantly more rapidly from amino acids than from hydrolysates. The results are also in agreement with previous in vitro observations on amino acid absorption from single peptides and equivalent amino acid mixtures. Thus, glycine and methionine were absorbed more rapidly from the dipeptide glycylmethionine than from the equivalent amino acid mixture only at high peptide concentrations. ${ }^{12}{ }^{13}$ At low concentrations the absorption rates were similar. Furthermore, the uptake of lysine from the dipeptide lysyl-lysine and an equivalent free amino acid mixture was shown to be more rapid from the free amino acid mixture at low concentrations but more rapid from the dipeptide at higher concentrations. ${ }^{6}$

In view of the great difficulty in demonstrating sodium dependence on active intestinal transport processes in vivo in man, even when sodium free solutions are perfused, ${ }^{14}{ }^{15}$ it seems highly unlikely that the relatively small variations in perfused sodium concentrations (111-146 mmol/l) (Table 2) are responsible for the observed differences in amino acid absorption. Concentration-dependent alterations in the relative amino acid transport rates from protein hydrolysates and amino acid mixture could be due to differences in the affinity and transport capacity of the peptide and free amino acid transport systems. One could imagine that at low concentrations amino acid absorption from amino acid mixtures, if mediated by a high affinity, low capacity free amino acid transport system, could be significantly greater than from protein hydrolysates. If the overall peptide transport system were of lower affinity but higher capacity this 'kinetic advantage' could shift in favour 
of protein hydrolysates as the concentration of peptides increases and saturation of the free amino acid transport system by amino acids released at the brush border occurs. This explanation must of necessity be tentative as confirmation would require considerably more detailed analysis of amino acid and peptide transport kinetics than is allowed by the results of the present studies.

The importance of the pattern of amino acid absorption from amino acid mixtures and protein hydrolysates has previously been emphasised.$^{45}$ During jejunal perfusion of a number of different protein hydrolysates and their equivalent amino acid mixtures $^{345}$ it has been observed that the variation in percentage amino acid absorption from the protein hydrolysates was considerably less than that seen with the equivalent amino acid mixtures. It was suggested that this observation might be of nutritional importance because of more 'even' presentation of the amino acids to the tissues for protein synthesis. While expression of the absorption rates of individual amino acids as a percentage of perfused load is valid and useful for comparing amino acid absorption from different nitrogen sources, the 'pattern' of absorption so obtained is quite different from the pattern one sees when absolute amounts of amino acid absorbed are considered, because percentage absorption takes no account of the wide variation in concentration of the amino acids in the perfusate-for example, compare histidine and glutamine (Table 1). The pattern of absolute amounts of amino acid absorbed is pre- sumably the more important for protein synthesis. In Fig. 1 amino acid absorption is expressed, firstly, as a percentage of the perfused load and in Fig. 2 as actual amounts of amino acid absorbed. Quite clearly the 'pattern' of presentation of amino acids to the tissue bears no relationship to the pattern of absorption obtained when the results are expressed as a percentage of the perfused load, but is, in fact, related to the composition of the solution perfused (Fig. 3), as previously demonstrated in vitro by Gardner, ${ }^{16} 17$ and in vivo in man by Marrs et al. ${ }^{18}$ A similar result was also obtained at 40 and $70 \mathrm{mmol} / 1$ total amino acid (results not shown). Previous studies quoted in support of the suggestion that protein hydrolysates may be superior to amino acid mixtures in terms of protein synthesis emphasised the importance of simultaneity of presentation of amino acids to the tissues for protein synhesis ${ }^{19}$ rather than that the actual amounts of amino acids were importnt in this respect. It is possible, but unproved, that rapid absorption of some amino acids from protein hydrolysates compared with equivalent amino acid mixtures shown in perfusion experiments will confer an advantage in protein synthesis in normal man fed orally with a hydrolysate. This possibility is the subject of further investigation.

Our results illustrate the fundamental importance of studying kinetic phenomena over a range of concentration since results at a single concentration are frequently misleading. ${ }^{20}$ Although we have shown no significant absorptive advantage due to either prepa-

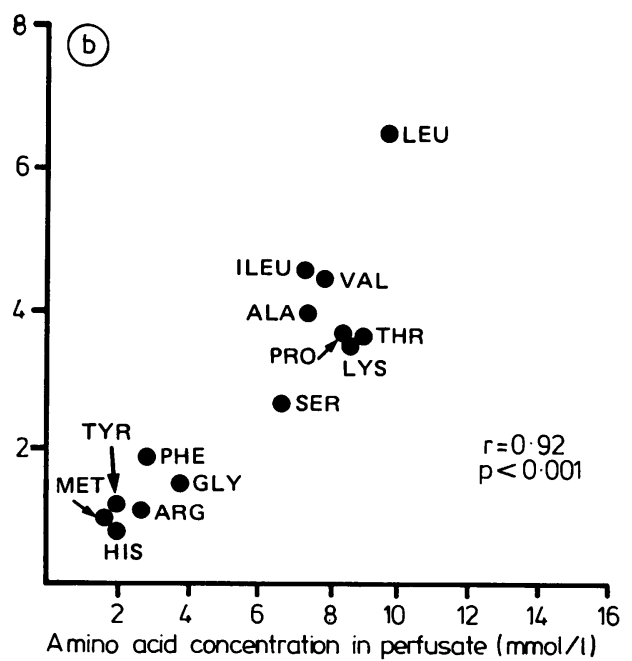

Fig. 3 Relation between absolute amounts of individual amino acids absorbed and the concentration of individual amino acids in the perfusion solutions. During perfusion of (a) protein hydrolysate containing $100 \mathrm{mmol} / \mathrm{l}$ $(1.32 \mathrm{~g} / 100 \mathrm{ml})$ total amino acid, and (b) amino acid mixture at the same concentration. 
ration the recommendation that chemically defined enteral diets should include protein hydrolysates containing small peptides rather than free amino acids as the nitrogen source is probably reasonable on the grounds of palatability, lower osmostic pressure, and lower cost. Further studies of absorption of amino acids, peptides, and whole protein nitrogen sources after meals and estimation of their effects on protein synthesis, however, are required to establish a nutritional case for or against the use of peptides in enteral diets.

The support of the Nestle Co., The Wellcome Foundation and the Joint Research Board of St. Bartholomew's Hospital is gratefully acknowledged.

\section{References}

1 Adibi SA, Mercer DW. Protein digestion in human intestine as reflected in luminal mucosal and plasma amino acid concentration after meals. J Clin Invest 1973; 52:1586-94.

2 Matthews DM. Intestinal absorption of peptides. Physiol Rev 1975; 55:537-608.

3 Silk DB, Marrs TC, Addison JM, Burston D, Clark ML, Matthews DM. Absorption of amino acids from an amino acid mixture simulating casein and a tryptic hydrolysate of casein in man. Clin Sci 1973; 45:715-9.

4 Silk DB, Marrs TC, Clegg KM, Addison JM, Burston D, Clark ML, Matthews DM. Absorption of an amino acid mixture simulating casein and an enzyme hydrolysate of casein prepared for oral administration to patients. Br J Nutr 1975; 33:95-100.

5 Fairclough PD, Hegarty JE, Silk DB, Clark ML. A comparison of the absorption of two protein hydrolysates and their effects on water and electrolyte movements in the human jejunum. Gut 1980; 21:829-34.

6 Burston D, Taylor E, Matthews DM. Kinetics of uptake of lysine and lysyl-lysine by hamster jejunum in vitro. Clin Sci 1980; 59:285-7.

7 Silk DB, Fairclough PD, Park NJ, Lane A, Webb JPW, Clark ML, Dawson AM. A study of relations between the absorption of amino acids, dipeptides, water and electrolytes in the normal human jejunum. Clin Sci Mol Med 1975; 49:401-8.

8 Sladen GE, Dawson AM. Further studies on the perfusion method for measuring intestinal absorption in man. The effects of proximal occlusive balloon and a mixing segment. Gut 1970; 11:947-54.

9 Wingate DL, Sandberg RJ, Phillips SF. A comparison of stable and ${ }^{14} \mathrm{C}$ labelled polyethylene glycol as volume marcators in the human jejunum. Gut 1977; 13:812-5.

10 Sladen GE, Dawson AM. Interrelationships between the absorption of glucose, sodium and water by the normal human jejunum. Clin Sci 1969; 36:119-32.

11 Snedecor GW, Cochrane WG. Statistical methods 6th ed. Iowa: Iowa State University Press, 1937.

12 Matthews DM, Lis MT, Chang B, Crampton RF. Observations on the intestinal absorption of some oligopeptides of methionine and glycine in the rat. Clin Sci 1969; 37:751-64.

13 Matthews DM, Craft IL, Geddes D, Wise IJ, Hyde CW. Absorption of glycine and glycine peptides from the small intestine of the rat. Clin Sci 1968; 35:415-24.

14 Adibi SA. Leucine absorption rate and net movements of sodium and water in human jejunum. J Appl Physiol 1970; 28:753-7.

15 Olsen WA, Ingelfinger FJ. The role of sodium in intestinal glucose absorption in man. J Clin Invest 1968; 47:1133-42.

16 Gardner MLG. Absorption of amino acids and peptides from a complex mixture in the isolated small intestine of the rat. J Physiol 1975; 253:233-56.

17 Gardner MLG. Absorption from a mixture of 17 free amino acids by the isolated small intestine of the rat. $J$ Physiol 1976; 225:563-74.

18 Marrs TC, Addison JM, Burston D, Matthews DM. Changes in plasma amino acid concentration in man after ingestion of an amino acid mixture simulating casein and a tryptic hydrolysate of casein. Br J Nutr 1975; 34:259-65.

19 Cannon PR, Steffee CH, Frazier LJ, Rowley DA, Steptoe RC. The influence of time of ingestion of essential amino acids upon utilisation and tissue synthesis. Fed Proc 1947; 6:390.

20 Dixon M, Webb EC. Enzyme kinetics. In: Enzymes. London: Longman, 1979: 55-138. 